\title{
Lipopolysaccharide inhibits triglyceride synthesis in dairy cow mammary epithelial cells by upregulating miR-27a-3p, which targets the PPARG gene
}

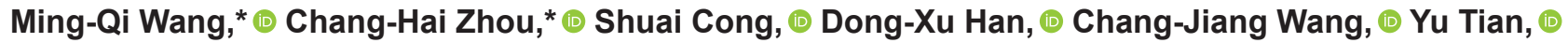

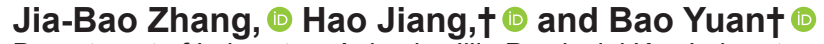 \\ Department of Laboratory Animals, Jilin Provincial Key Laboratory of Animal Model, Jilin University, Changchun 130062, Jilin, P.R. China
}

\section{ABSTRACT}

The fat content of milk determines the quality of milk, and triglycerides are the major components of milk fat. Milk fat synthesis is regulated by many factors. Lipopolysaccharide (LPS) has been shown to inhibit milk fat synthesis in bovine mammary epithelial cells, but research on the underlying mechanisms has been limited. MicroRNA (miRNA) are involved in many physiological processes, but there have been few studies on their regulation in milk fat synthesis. In this study, we aimed to investigate whether LPS upregulates miR-27a-3p, which targets PPARG, thereby inhibiting the synthesis of triglycerides in a dairy cow mammary epithelial cell line (MAC-T). After LPS stimulation of MAC-T cells, PPARG gene expression and milk fat synthesis were inhibited. TargetScan software was used to predict miRNA targeting $P P A R G$, and miR-27a-3p was selected as a candidate. A dual luciferase reporter assay further confirmed the targeting connection between miR-27a-3p and the PPARG gene. To investigate the functions of miR-27a-3p, miR-27a-3p mimic and inhibitors were transfected into MAC-T cells. The mRNA and protein levels of $P P A R-\gamma$ were negatively correlated with the expression of miR-27a-3p. Lipid droplet accumulation and triglyceride synthesis were also negatively correlated with miR-27a-3p expression. Inhibition of miR-27a-3p partially reversed the LPSinduced decreases in PPARG expression and milk fat synthesis. In summary, our results reveal that LPS can inhibit MAC-T cell milk fat synthesis by upregulating miR-27a-3p, which targets the PPARG gene.

Key words: lipopolysaccharide, triglyceride, miR-27a3p, PPARG

\footnotetext{
Received January 27, 2020.

Accepted August 19, 2020.

*These authors contributed equally to this work.

†Corresponding authors: jhhaojiang@jlu.edu.cn and yuan_bao@jlu edu.cn
}

\section{INTRODUCTION}

Milk is a widely used drink in human daily life. The fat content in milk is one of the main indicators of milk quality ( $\mathrm{Lu}$ et al., 2016). Milk fat synthesis is affected by a variety of factors (Liu et al., 2018b); for example, when dairy cows suffer from mastitis, their milk fat synthesis levels are significantly reduced (Hu et al., 2019). Lipopolysaccharide is a key antigenic factor for dairy cow mastitis pathogens such as Escherichia coli (Brade et al., 2013). Numerous genes are involved in milk fat synthesis in dairy mammary epithelial cells, such as PPARG (Liu et al., 2016a), FABP3 (Bionaz and Loor, 2008a), FASN (Schennink et al., 2009), and CRTC2 (Zhang et al., 2019). Related studies have confirmed that LPS inhibits milk fat synthesis by inhibiting the expression of genes associated with milk fat synthesis in bovine mammary epithelial cells (Liu et al., 2015; Wang et al., 2018a; Chen et al., 2019). Lipopolysaccharide can also increase the expression of proinflammatory factors in cow mammary epithelial cells, aggravate the inflammatory response of cow mammary gland tissue, and cause the normal physiological structure of cow mammary gland tissue to be damaged (Wu et al., 2016; Li et al., 2019a). However, research on the potential molecular mechanisms of the LPS-induced reduction in milk fat synthesis in dairy cows has been limited.

Peroxisome proliferator-activated receptor gamma $(P P A R G)$ is a member of the nuclear receptor family, which is expressed in a variety of tissues and organs (Marion-Letellier et al., 2016). The PPARG is mainly responsible for the catabolism of lipids and is also related to a variety of illnesses, such as obesity (Shao et al., 2016), diabetes (Wang et al., 2017c), arteriosclerosis (Zhang et al., 2017), and cancer (Ramer et al., 2013). Analyses of transcriptome data have shown that the PPARG gene can regulate lipid metabolism in goat mammary epithelial cells (Shi et al., 2016). In goats, PPARG enhances the synthesis of monounsaturated fatty acids by controlling stearoyl-CoA desaturase (Shi et al., 2013). In addition, our research group found 
that the PPARG gene can be regulated by microRNA (miRNA) in dairy cow epithelial cells to affect triglyceride synthesis (Zhang et al., 2019). Related research has also confirmed that miRNA participate in the regulation of milk fat synthesis (Shen et al., 2016).

The miRNA are a type of noncoding single-stranded RNA molecule encoded by endogenous genes that are typically 19 to 23 nucleotides in length and participate in posttranscriptional gene expression regulation in animals and plants (Bushati and Cohen, 2007; Mohr and Mott, 2015; Lu and Rothenberg, 2018). The miRNA are involved in many biological functions, such as cell proliferation (Zheng et al., 2017), apoptosis (Song et al., 2017), differentiation (Martin et al., 2016), and tissue development (Horak et al., 2016). Previous studies have shown that a variety of miRNA are involved in milk fat synthesis. For example, miR-224 inhibits milk fat secretion by targeting the ACADM and ALDH2 genes in mammary epithelial cells (Shen et al., 2017). The MiR-21-3p promotes triglyceride secretion in cow mammary epithelial cells by inhibiting the expression of the Elovl5 gene (Li et al., 2019b). These discoveries indicate that miRNA play crucial roles in milk fat synthesis in mammary epithelial cells. The MiR-27a-3p is a miRNA molecule that is highly conserved among many species and has many biological functions (Xi et al., 2018). In mice, miR-27a-3p affects the balance of reproductive hormones by targeting the Creb1 gene in granular cells (Wang et al., 2017b). The miR-27a$3 \mathrm{p}$ is able to ameliorate the inflammatory response by activating Toll-like receptors, which in turn have a protective effect on the spinal cord (Zhang et al., 2018b). In addition, related studies have found that miR-27a-3p can regulate milk fat synthesis in primary cells of bovine mammary glands (Tang et al., 2017a). However, whether LPS can regulate milk fat synthesis in dairy cow mammary epithelial cells via miRNA has not been determined.

In this study, to explore the underlying mechanism of the LPS-induced decrease in milk fat synthesis, we used LPS to stimulate dairy cow mammary epithelial cells, detect changes in milk fat and PPARG expression, and screen for miRNA that may target the $P P A R G$ gene. We further validated our hypothesis by using methods such as dual luciferase, quantitative reverse-transcription PCR (qRT-PCR), and oil red O staining assays to investigate whether LPS can inhibit dairy cow mammary epithelial cell (MAC-T) milk fat synthesis by upregulating miR-27a-3p, which targets the PPARG gene. Our results are intended to provide a new theoretical basis for LPS-induced inhibition of milk fat synthesis in MAC-T cells.

\section{MATERIALS AND METHODS}

\section{Cell Culture and Treatment}

The MAC-T cell line is an immortalized dairy cow mammary epithelial cell line. The MAC-T cells were cultured using $25-\mathrm{cm}^{2}$ cell culture flasks with DMEM/ F12 medium (HyClone, South Logan, UT) containing $10 \%$ fetal bovine serum (Gibco, Grand Island, NY) and $1 \%$ antibiotic-antimycotic mixture (HyClone). The cell culture flasks were placed in a constant-temperature incubator containing $5 \% \mathrm{CO}_{2}$ and incubated at $37^{\circ} \mathrm{C}$. In addition, a $1 \mathrm{mg} / \mathrm{mL}$ stock solution was prepared by dissolving LPS (Sigma, St. Louis, MO) in sterile PBS. The final stimulation concentration of LPS was set to $10 \mu \mathrm{g} / \mathrm{mL}$. The LPS stimulation time was set to $24 \mathrm{~h}$. Three replicate wells were used for each experiment.

\section{Dual Luciferase Reporter Assay}

We used the TargetScan (http://www.targetscan .org/mmu_72/) to predict miRNA that may target the PPARG 3'UTR (Agarwal et al., 2015). First, we selected a species as cow, then entered the gene as PPARG. After submitting this information, we got the results of "predicted consequential pairing of target region and miRNA, site type, context ++ score, context ++ score percentile, weighted context ++ score, conserved branch length and $\mathrm{P}_{\mathrm{CT}}$." As repeated check, we also used the Perl script tool of the TargetScan (http://www .targetscan.org/mmu_72/mmu_72_data_download/ targetscan_70.zip) to predict the miRNA target position of PPARG (NM_181024.2) 3'UTR in the cow (Lewis et al., 2005). The mature sequence of miRNA was obtained from the miRBase Sequence Database (Griffiths-Jones et al., 2006). Because of the results of the TargetScan web and the TargetScan Perl script was not the same, we used the result of Perl script and sequence information from NCBI (NM_181024.2) as the final criteria.

PmiR-PPARG - $3^{\prime} \mathrm{UTR}$-wild type (WT) plasmid and pmiR-PPARG-3'UTR-mutant (MUT) plasmid were established to test the target sites of the PPARG $3^{\prime} \mathrm{UTR}$ and bta-miR-27a-3p (Supplemental Files S1 and S2 and Supplemental Figures S1-S3, https://doi.org/10.3168/ jds.2020-18270). The plasmids used in this study were constructed by Guangzhou Ruibo Biological Company (Guangzhou, China). The 293T cells were cultured in 12-well cell culture plates $24 \mathrm{~h}$ before transfection with 3 duplicate wells per group. The vectors were transfected into 293T cells with or without bta-miR-27a-3p mimic. After $48 \mathrm{~h}$ of transfection, the fluorescence intensity was determined on the basis of the manufacturer's protocol. 


\section{Transfection with miRNA Mimic and Inhibitor}

After the cell cultures stabilized, we used trypsin to digest MAC-T cells and seeded the cells in 12-well cell culture plates at a density of approximately $4 \times 10^{5}$ cells per well with 3 duplicate wells per group. Mimic and inhibitor of miR-27a-3p were designed and synthesized by Guangzhou Ruibo Biological Company (Guangzhou, China). For every transfection well, we mixed $60 \mu \mathrm{L}$ of $1 \times$ buffer and $5 \mu \mathrm{L}$ of miR-27a-3p mimic/inhibitor for $10 \mathrm{~min}$ at room temperature. Then, $6 \mu \mathrm{L}$ of reagent was added to the mixture. The final concentrations of the miR-27a-3p mimic and inhibitor were $100 \mathrm{n} M$. The transfection time was set to $24 \mathrm{~h}$.

\section{RNA Isolation and qRT-PCR}

TRIzol reagent (Invitrogen, Carlsbad, CA) was applied to extract total RNA from the cells in accordance with the manufacturer's instructions. A NanoDrop 2000 spectrophotometer (Thermo, Waltham, MA) was used to evaluate the concentration and quantity of RNA, and RNA samples with optical density at 260/280 nm (OD 260/280) values between 1.8 and 2.0 were considered acceptable. We further used a reverse transcription kit to synthesize cDNA (Tiangen, Beijing, China); qRT-PCR was performed using SuperReal PreMix Plus (SYBR Green; Tiangen) with a CFX96 Real-Time PCR system (Bio-Rad, Hercules, CA). $\beta$-Actin and U6 were used as endogenous control genes. The $2^{-\Delta \Delta \mathrm{CT}}$ method was applied to calculate the relative expression of genes. The primers we applied were synthesized by Kumei Biological Company of Jilin Province (Changchun, China). All the primers applied are listed in Supplemental Table S1 (https://doi.org/10.3168/jds.2020-18270).

\section{Flow Cytometry}

An Annexin V/PI Kit (Solarbio, Beijing, China) was applied to detect MAC-T cell apoptosis rates in accordance with the manufacturer's instructions. Twentyfour hours after transfection, MAC-T cells were washed with PBS, digested with trypsin, and centrifuged at 176 $\times g$ at room temperature for 5 min to collect cell pellets. After resuspension in binding buffer, the cells were stained sequentially with Annexin $\mathrm{V}$ and propidium iodide and detection was completed within $1 \mathrm{~h}$.

\section{Western Blot Analysis}

Radioimmunoprecipitation assay (RIPA) lysis buffer (Solarbio) was used to extract total protein from the cells. The extracted protein samples were quantified using a BCA kit (Solarbio). The total proteins were separated via $12 \%$ SDS-PAGE (Solarbio). Then, the proteins were transferred to a PVDF membrane (Millipore, Bedford, MA) for $1 \mathrm{~h}$. The PVDF membrane was blocked in a $5 \%$ skim milk powder-Tris-buffered saline with Tween 20 solution at room temperature for $3 \mathrm{~h}$ and then incubated with a primary anti-PPAR $\gamma$ antibody (1:500, Abcam, Cambridge, UK) and an antiGAPDH antibody $(1: 1,000$, Abcam $)$ overnight at $4^{\circ} \mathrm{C}$. The next morning, the PVDF membrane was washed with Tris-buffered saline with Tween 20 (10 min/wash, 3 times in total) and then incubated with a secondary antibody (goat anti-rabbit IgG, Abcam) at room temperature. Chemiluminescence substrates (Tanon, Shanghai, China) were used to visualize the protein bands, and the ImageJ program was used for quantification.

\section{Oil Red O Staining}

An oil red O staining kit (Solarbio) was used to stain lipid droplets in MAC-T cells. The MAC-T cells were washed with $\mathrm{PBS}$, fixed and stained with oil red $\mathrm{O}$ dye for $20 \mathrm{~min}$. After the oil red $\mathrm{O}$ dye was washed away with distilled water, the nucleus was stained with hematoxylin staining solution for $1 \mathrm{~min}$. Finally, the hematoxylin stain was washed off, and the MAC-T cells were covered with distilled water. Lipid droplets were observed under a microscope at 400× magnification.

\section{Triglyceride Assay}

The levels of cellular triglyceride (TAG) in MAC$\mathrm{T}$ cells were assayed using the tissue/cell triglyceride assay kit (Applygen, Beijing, China). Total protein concentrations were determined by the BCA assay (Solarbio). All experiments were performed according to the manufacturer's instructions. The values obtained were normalized to the total cellular protein content and were expressed as micromoles per gram of protein.

\section{Statistical Analysis}

All experiments were performed in triplicate. The experimental data are expressed as the mean \pm standard deviation of the mean. Significant differences were evaluated through one-way ANOVA for multiple comparisons using SPSS 19.0 software (SPSS Inc., Chicago, IL). $P<0.05$ was deemed to indicate statistical significance; $P<0.01$ was deemed to indicate extreme significance. 

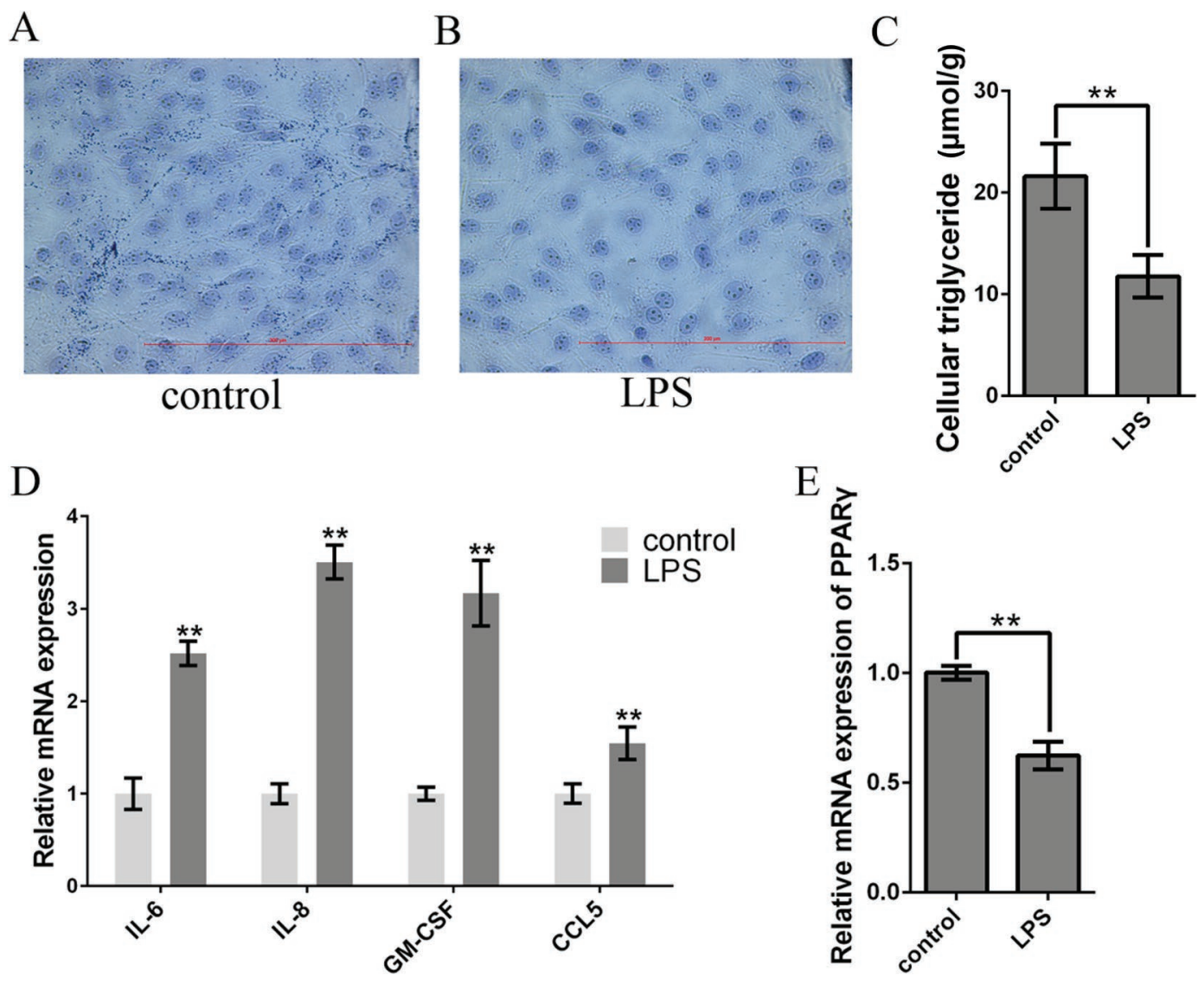

Figure 1. Lipopolysaccharide inhibits milk lipid synthesis and PPARG expression in dairy cow mammary epithelial (MAC-T) cells. Control: normally cultured MAC-T cells; LPS: MAC-T cells were stimulated with LPS at a concentration of $10 \mu \mathrm{g} / \mathrm{mL}$ for $24 \mathrm{~h}$. (A, B) Oil red O staining $(400 \times$; scale: $200 \mu \mathrm{m})$ indicating lipid droplet aggregation changes in MAC-T cells after LPS stimulation for $24 \mathrm{~h}$. (C) The triglyceride production of MAC-T cells after LPS stimulation for $24 \mathrm{~h}$. (D) The relative mRNA expression levels of inflammation-promoting factors after LPS stimulation for $24 \mathrm{~h}$. (E) The relative mRNA expression levels of PPARG after LPS stimulation for $24 \mathrm{~h}$. All experiments were performed in triplicate. The data are shown as the means $\pm \mathrm{SD} . * * P<0.01$.

\section{RESULTS}

\section{LPS Inhibits Milk Fat Synthesis and PPARG Expression in MAC-T Cells}

To explore the effect of LPS on milk fat synthesis in MAC-T cells, we used oil red $\mathrm{O}$ staining and a triglyceride quantification kit to detect changes in milk fat levels after LPS stimulation. The oil red O staining results revealed that LPS stimulation inhibited the accumulation of lipid droplets in MAC-T cells (Figure 1A-B). Similarly, the triglyceride quantification results showed that LPS stimulation inhibited triglyceride synthesis in MAC-T cells $(P<0.01$; Figure $1 \mathrm{C})$. We also examined the changes in proinflammatory factors in MAC-T cells after LPS stimulation. Our qRT-PCR results showed that the expression of the proinflammatory factors IL6 $(P<0.01), I L 8(P<0.01)$, GM$C S F(P<0.01)$, and $C C L 5(P<0.01)$ significantly increased after LPS stimulation (Figure 1D). Given that $P P A R G$ is a pivotal factor in milk fat synthesis, we tested the effect of LPS on PPARG by qRT-PCR, and our results revealed that the expression of $P P A R G$ was significantly reduced after LPS stimulation of MAC-T cells $(P<0.01$; Figure 1E).

\section{Validation of the Relationship Between miR-27a-3p and PPARG Was Verified by a Dual Luciferase Reporter Assay}

Based on the information we got from the prediction, we selected miR-27a-3p, miR-128, and miR-454 as representatives (Supplemental Table S2, https://doi .org/10.3168/jds.2020-18270). Our qRT-PCR results showed that after MAC-T cells were stimulated by LPS, the expression of miR-103 $(P>0.05)$ did not change significantly, whereas the expression of miR27a-3p $(P<0.01)$, miR-128 $(P<0.01)$, and miR-454 $(P<0.01)$ increased significantly (Figure $2 \mathrm{~A})$. Then, 
we selected miR-27a-3p as a candidate miRNA for subsequent research. The target site is shown in Figure 2B. Furthermore, our dual luciferase reporter assay results illustrated that the cells cotransfected with miR-27a-3p mimic and the bta-PPARG-WT vector had markedly lower luciferase activity than the negative control (NC) cells $(P<0.01)$. With mutations of its predicted target site, luciferase activity was significantly increased in 293T cells compared with the activity in bta-PPARGWT cells cotransfected with miR-27a-3p mimic $(P<$ 0.01; Figure 2C).

\section{MiR-27a-3p Regulates PPARG Expression in MAC-T Cells}

After transfection of cells with miR-27a-3p mimic and inhibitor, our flow cytometry findings showed that there were no obvious differences in the apoptosis rates of MAC-T cells among the groups $(P>0.05$; Figure 3A-E). Our qRT-PCR results demonstrated that the expression level of miR-27a-3p was signifi- cantly upregulated in the mimic group compared with the NC group $(P<0.01)$, whereas it was significantly decreased in the inhibitor group compared with the inhibitor NC (I-NC) group $(P<0.01$; Figure $3 \mathrm{~F})$. The above results indicated that miR-27a-3p was successfully overexpressed and inhibited in the corresponding groups. In addition, transfection with the miR-27a-3p mimic significantly downregulated the expression of the $P P A R G$ gene compared with that in the NC group $(P$ $<0.01$ ); in contrast, transfection with the miR-27a-3p inhibitors significantly elevated the expression of the PPARG gene compared with that in the I-NC group $(P<0.05 ;$ Figure $3 \mathrm{G})$. Similarly, Western blot analysis illustrated that MAC-T cells transfected with the miR27a-3p mimic showed lower levels of PPARG protein than the cells in the NC group $(P<0.01)$, whereas MAC-T cells transfected with miR-27a-3p inhibitors showed higher levels of PPARG protein than the cells in the I-NC group $(P<0.05$; Figures $3 \mathrm{H}$ and $3 \mathrm{I})$. The above findings indicated that miR-27a-3p suppresses the expression of the target gene PPARG.
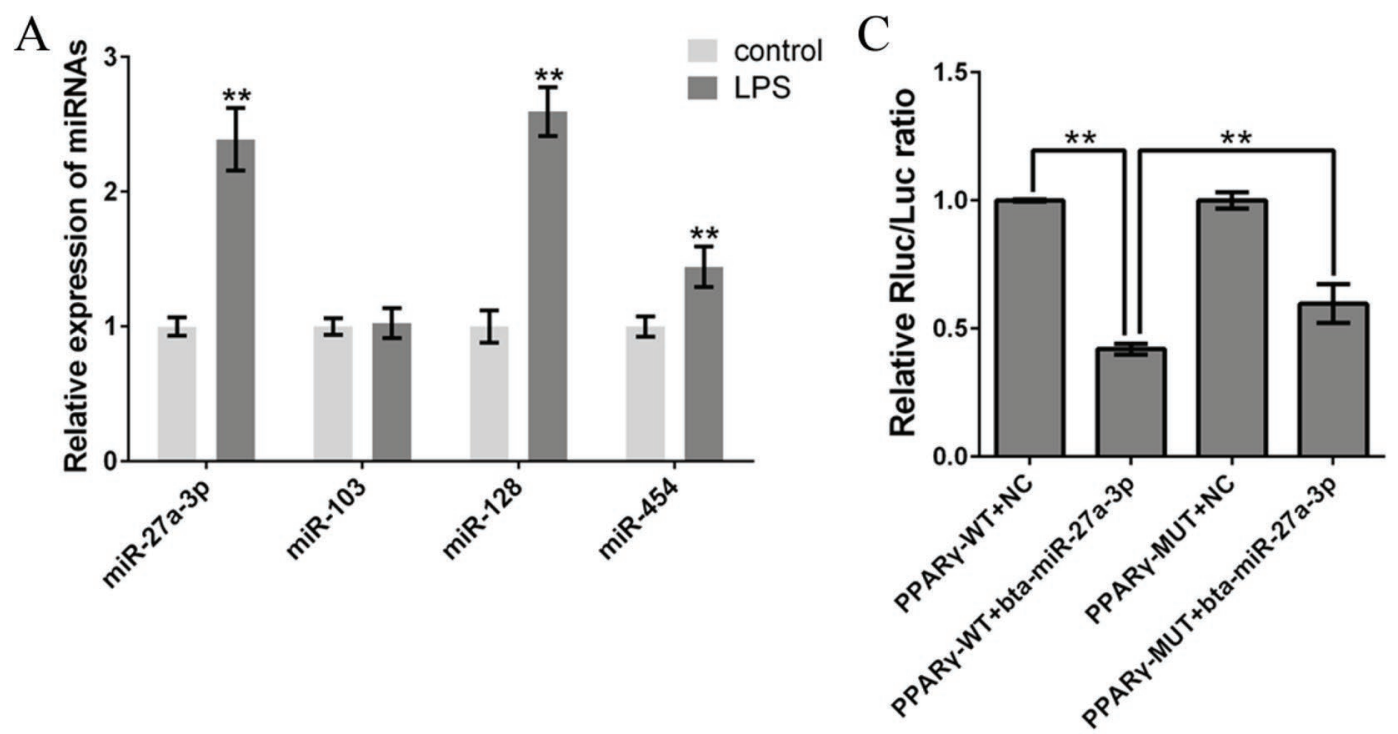

B

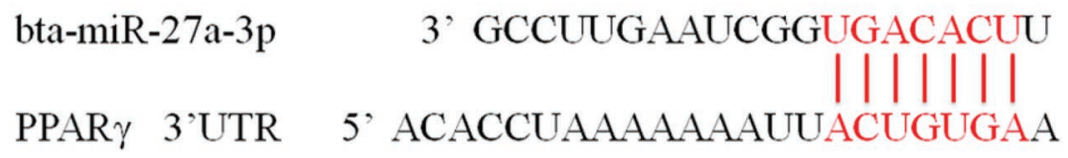

Figure 2. Screening for microRNA (miRNA) that may target PPARG. Control: normally cultured dairy cow mammary epithelial (MAC-T)

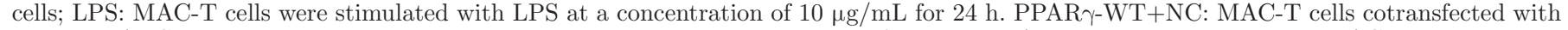

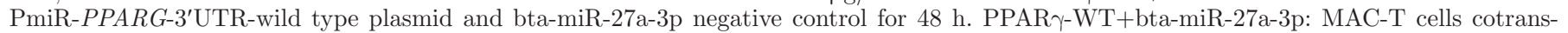

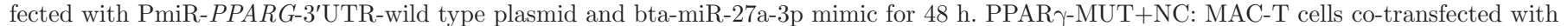

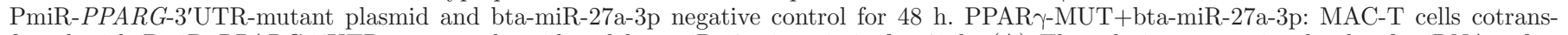
fected with PmiR-PPARG-3'UTR-mutant plasmid and bta-miR-27a-3p mimic for 48 h. (A) The relative expression levels of miRNAs after

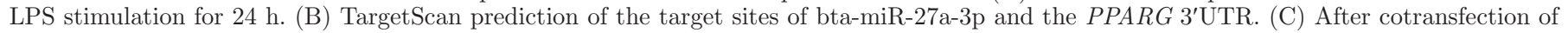

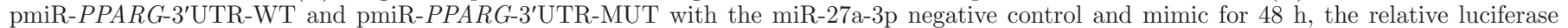

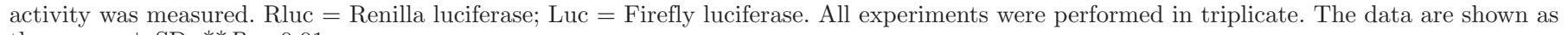
the means $\pm \mathrm{SD} .{ }^{* *} P<0.01$ 


\section{MiR-27a-3p Inhibits MAC-T Cell Lipid Synthesis}

The results of oil red O staining showed that transfection with miR-27a-3p mimic suppressed the aggregation of lipid droplets, whereas miR-27a-3p knockdown increased the aggregation of lipid droplets (Figures $4 \mathrm{~A}-\mathrm{D})$. In addition, the triglyceride assay revealed that transfection with miR-27a-3p mimic reduced the triglyceride content, whereas transfection with miR-27a$3 \mathrm{p}$ inhibitors had the opposite effect $(P<0.05$; Figure $4 \mathrm{E})$.

\section{Inhibition of miR-27a-3p Partially Reverses the LPS-Induced Decrease in Milk Fat Synthesis in MAC-T Cells}

To further determine whether LPS can inhibit MAC$\mathrm{T}$ cell milk fat synthesis by upregulating miR-27a-3p, we used both LPS and miR-27a-3p inhibitor to treat MAC-T cells together for $24 \mathrm{~h}$ and then examined changes in milk fat synthesis and PPARG expression. The oil red $\mathrm{O}$ staining, triglyceride quantification, and qRT-PCR outcomes revealed that inhibition of miR-
A

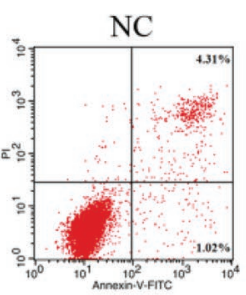

$\mathrm{C}$

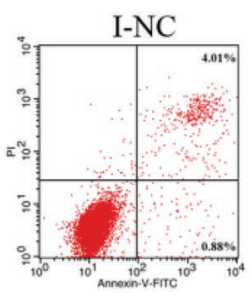

B

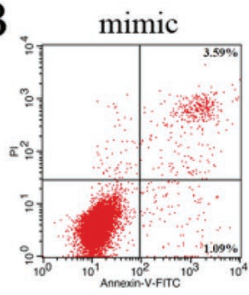

$\mathrm{D}$

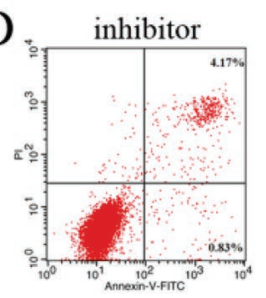

$\mathrm{E}$

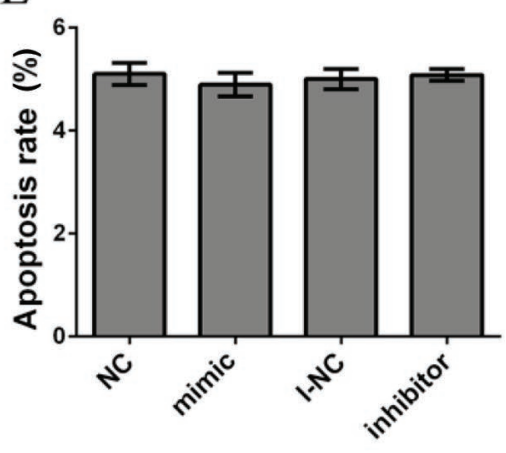

$\mathrm{F}$

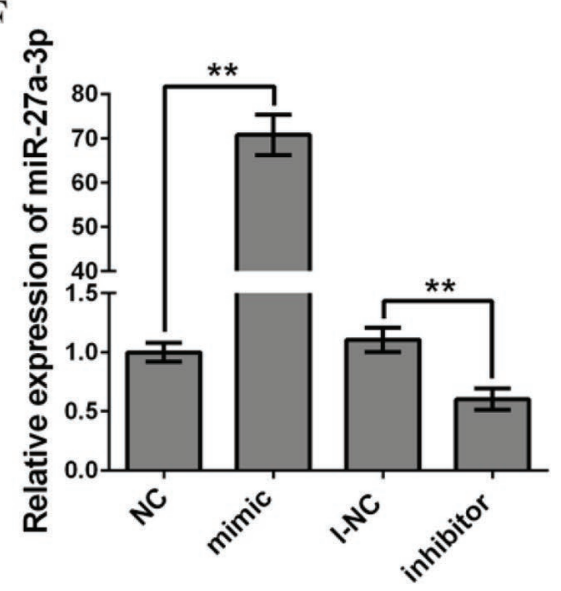

G
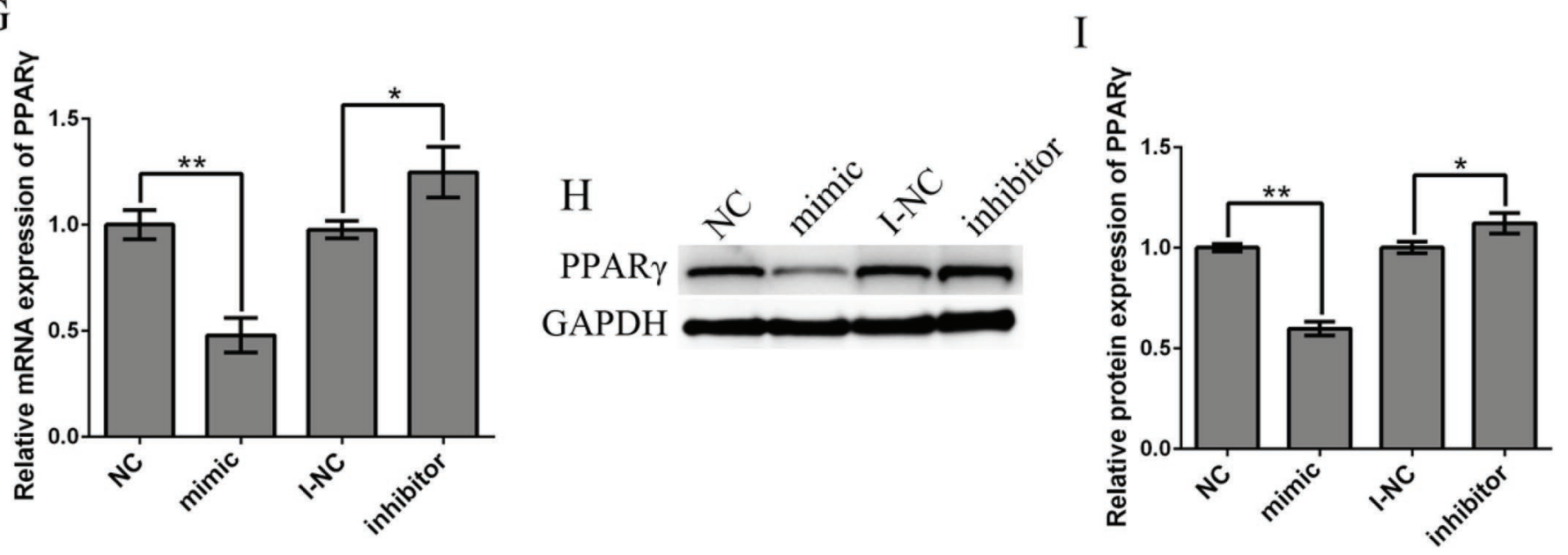

Figure 3. MiR-27a-3p regulates PPARG expression in dairy cow mammary epithelial (MAC-T) cells. NC: MAC-T cells transfected with miR-27a-3p negative control for $24 \mathrm{~h}$; mimic: MAC-T cells transfected with miR-27a-3p mimic for $24 \mathrm{~h}$; I-NC: MAC-T cells transfected with miR-27a-3p inhibitor negative control for $24 \mathrm{~h}$; inhibitor: MAC-T cells transfected with miR-27a-3p inhibitor for $24 \mathrm{~h}$. (A-E) After transfection with miR-27a-3p mimic and inhibitor for $24 \mathrm{~h}$, flow cytometry was used to detect the apoptosis rate of MAC-T cells. (F) The relative expression levels of miR-27a-3p after miR-27a-3p mimic and inhibitor transfection. (G) The relative mRNA expression levels of PPARG after miR-27a-3p mimic and inhibitor transfection. (H, I) The relative protein expression levels of PPARG after transfection with miR-27a-3p mimic and inhibitor. All experiments were performed in triplicate. The data are shown as the means \pm SD. ${ }^{*} P<0.05,{ }^{* *} P<0.01$. 
A

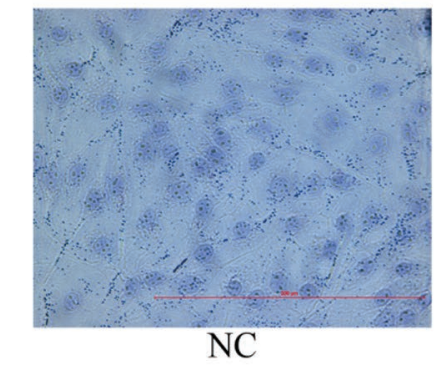

$\mathrm{C}$

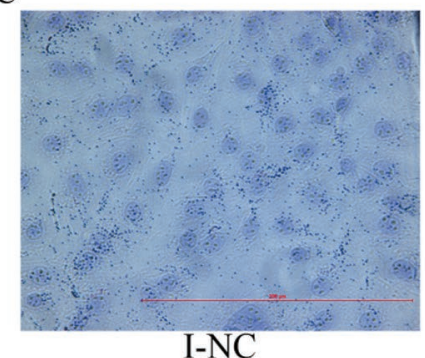

B

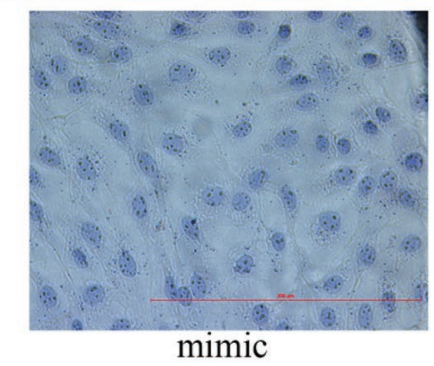

$\mathrm{D}$

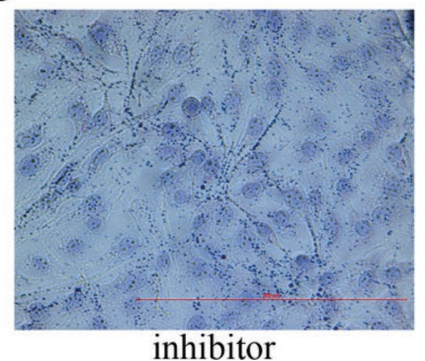

$\mathrm{E}$

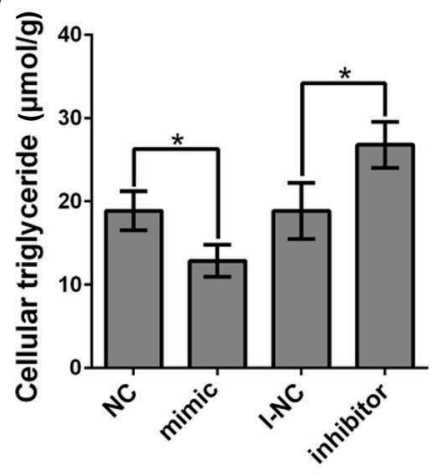

Figure 4. MiR-27a-3p inhibits dairy cow mammary epithelial (MAC-T) cell lipid synthesis. NC: MAC-T cells transfected with miR-27a-3p negative control for $24 \mathrm{~h}$; mimic: MAC-T cells transfected with miR-27a-3p mimic for $24 \mathrm{~h}$; I-NC: MAC-T cells transfected with miR-27a-3p inhibitor negative control for $24 \mathrm{~h}$; inhibitor: MAC-T cells transfected with miR-27a-3p inhibitor for $24 \mathrm{~h}$. (A-D) After transfection with miR27a-3p mimic and inhibitor for $24 \mathrm{~h}$, red O staining (400×; scale: $200 \mu \mathrm{m}$ ) was used to indicate lipid droplet aggregation in MAC-T cells.(E) Triglyceride production by MAC-T cells after miR-27a-3p mimic and inhibitor transfection for $24 \mathrm{~h}$. All experiments were performed in triplicate. Data are shown as the means $\pm \mathrm{SD} .{ }^{*} P<0.05$.

27a-3p partially reversed the decreases in milk fat synthesis and PPARG expression caused by LPS in MAC-T cells $(P<0.05$; Figure $5 \mathrm{~A}-\mathrm{E})$. All of the above results indicate that LPS can upregulate the expression of miR-27a-3p in MAC-T cells, thereby inhibiting PPARG expression and milk fat synthesis.

\section{DISCUSSION}

Mammary epithelial cells are the main bearers of lactation in dairy cows (Perruchot et al., 2016). They are also an important research object for studying lipid metabolism in dairy cows (Qi et al., 2018); MAC-T cells are an immortalized cow mammary epithelial cell line. This cell line has the advantages of rapid growth and stable passage. Researchers have used MAC-T cells as a research object to study the regulation of lipid metabolism (Johnson et al., 2010; Wang et al., 2018b). However, compared with cow mammary epithelial primary cells, MAC-T cells have defects in relatively insufficient lactation capacity. This should be considered in future research.

Triglycerides are critical components of milk fat, making up $98 \%$ or more of the substance (Khan et al., 2019). The triglyceride content is an important evaluation index for the quality of milk. (Qi et al., 2018). Milk fat synthesis is affected by many factors.
Studies on hormone-regulated lactation have found that melatonin secreted by the mammalian pineal gland inhibits the synthesis of triglycerides in mammary gland epithelial cells by inhibiting the mTOR signaling pathway (Wang et al., 2019). In addition, the versatile cytokine interferon- $\gamma$ can induce autophagy in dairy cow mammary epithelial cells through the GCN2 signaling pathway and reduce L-arginine content, ultimately inhibiting the synthesis of milk fat (Xia et al., 2016). Lipopolysaccharide is a crucial antigen of gramnegative bacteria that is released in large quantities after cows develop mastitis. After interacting with cells in the body, LPS induces the production of a variety of cytokines, thereby exerting toxic effects (Schmitz et al., 2004). After entering the cow, LPS can reduce the immunity of dairy cows and simultaneously reduce their milk yield and milk quality (Ning et al., 2018). The toxic effects of LPS on dairy cows not only affect their welfare but also cause massive economic losses to the dairy farming industry that severely affect their development (Jeong et al., 2017). In addition, LPS can inhibit the expression of genes related to milk fat synthesis in dairy cow mammary epithelial cells, which ultimately leads to reductions in milk fat synthesis (Liu et al., 2016b). However, thorough research on the molecular mechanisms by which LPS reduces milk fat synthesis in dairy cow mammary epithelial cells has been limited. Previ- 
ous studies have found that LPS at a concentration of $10 \mu \mathrm{g} / \mathrm{mL}$ can inhibit milk fat synthesis in dairy mammary epithelial cells (Wang et al., 2018a). Based on this study, we also used $10 \mu \mathrm{g} / \mathrm{mL}$ of LPS to stimulate MAC-T cells. Our results show that this concentration of LPS can significantly $(P<0.01)$ inhibit the milk fat synthesis of MAC-T cells and significantly $(P<0.01)$ inhibit the expression of the key factor PPAR $\gamma$ in the milk fat synthesis network. Therefore, we chose LPS at a concentration of $10 \mu \mathrm{g} / \mathrm{mL}$. Moreover, LPS has been shown to be able to upregulate the expression of a variety of proinflammatory factors in tissues and cells, exacerbating the inflammatory response (Yu et al., 2017; Zhang et al., 2018a). In our study, we selected IL-6, IL-8, GM-CSF, and CCL5 as representatives to evaluate the effects of LPS stimulation on MAC-T cell proinflammatory factors. The qRT-PCR results showed that the expression of the selected proinflammatory factors was significantly $(P<0.01)$ upregulated after MAC-T cells were stimulated with $10 \mu \mathrm{g} / \mathrm{mL}$ LPS for $24 \mathrm{~h}$. The above results indicated that LPS cannot only inhibit the milk fat synthesis of MAC-T cells, but also induce the upregulation of its proinflammatory factors.

Peroxisome proliferator-activated receptor gamma $(P P A R G)$ is a member of the PPAR family and is a key regulator of fat synthesis (Xu et al., 2018). In studies on adipocytes, adiponectin has been shown to promote preadipocyte differentiation through the PPARG pathway (Yang et al., 2018). Plant extracts, such as lentinan, can inhibit the PPARG/AKT signaling pathway in 3T3-L1 cells, thereby inhibiting the differentiation of the cells ( $\mathrm{Li}$ et al., 2015b). In addition, studies on knockout mice have confirmed that deletion of the PPARG gene causes atrophy of adipose tissue
A

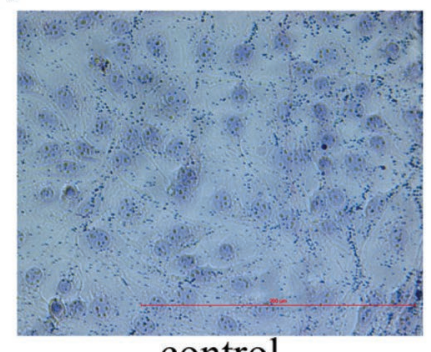

control
B

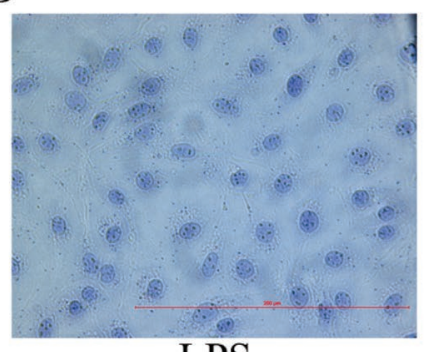

C

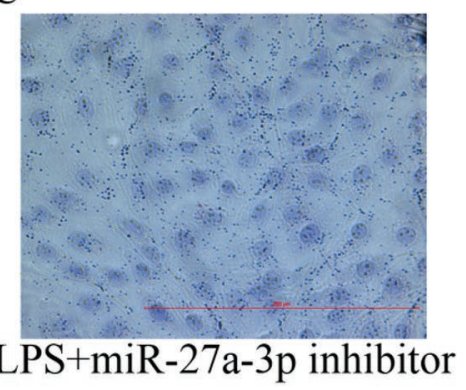

$\mathrm{D}$

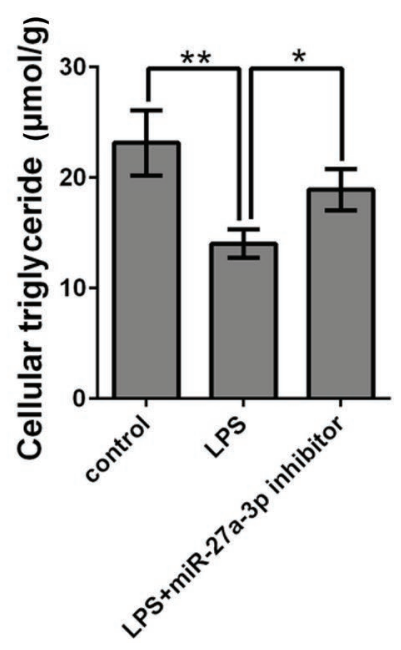

E

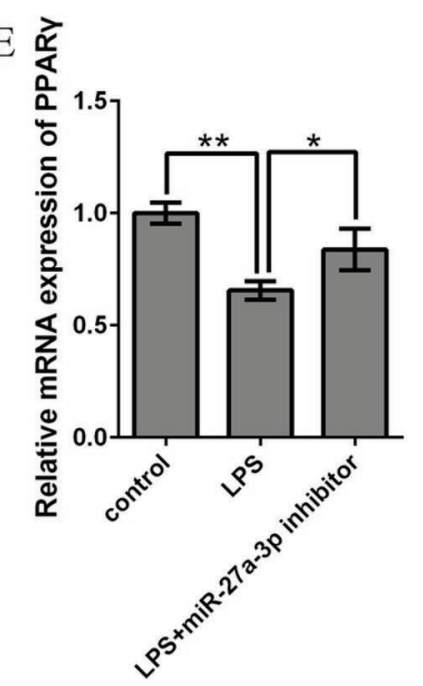

Figure 5. Inhibition of miR-27a-3p partially reversed the LPS-induced decrease in lipid synthesis in dairy cow mammary epithelial (MAC-T)

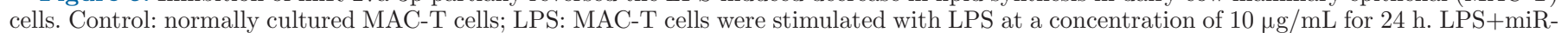

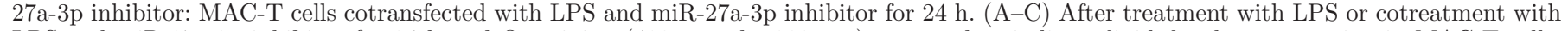

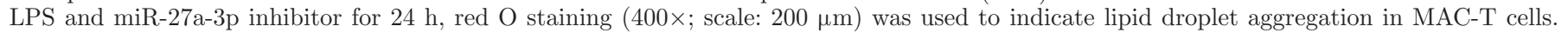

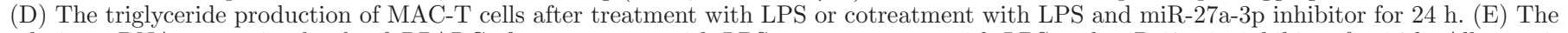

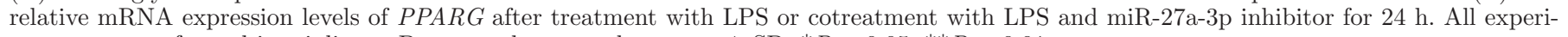
ments were performed in triplicate. Data are shown as the means $\pm \mathrm{SD}$. $* P<0.05, * * P<0.01$. 
and disturbance of fat metabolism (Wang et al., 2013). Furthermore, studies have confirmed that $P P A R G$ is a key member of the milk fat synthesis gene network in dairy cows (Invernizzi et al., 2010). Notably, miR-130 can target PPARG in dairy cow mammary epithelial cells to inhibit milk fat synthesis (Yang et al., 2017). In our research, the qRT-PCR and TAG assay results indicated that LPS can inhibit the expression of PPAR $\gamma$ and the synthesis of milk fat in MAC-T cells. Studies have shown that miRNA are involved in biological effects caused by LPS, such as angiogenesis ( $\mathrm{Li}$ et al., 2017), inflammation (Liu et al., 2017), and sepsis (Ma et al., 2019). Meanwhile, our results revealed that LPS can upregulate the expression of miRNA such as miR-27a-3p and miR-128, which may target PPARG. Therefore, miRNA may participate in the inhibition of milk fat synthesis in MAC-T cells induced by LPS.

MicroRNA is an indispensable posttranscriptional regulatory factor that participates in the regulation of genes by binding to the $3^{\prime} \mathrm{UTR}$ region of the target gene and thus participates in many biological processes (Creugny et al., 2018). MicroRNAs have been shown to be widely involved in fat metabolism. The 3T3-L1 preadipocyte cell line is an important model for studying fat metabolism and is one of the most commonly used cell lines for establishing adipocyte models (Zebisch et al., 2012). MicroRNA-185 restrains 3T3-L1 cell differentiation by targeting sterol regulatory element binding protein 1 (SREBP-1) and reduces lipid accumulation (Ning et al., 2017). In signaling pathway studies, miR206-3p has been found to inhibit the differentiation of 3T3-L1 cells by downregulating the expression of $c$-Met and to subsequently inactivate the PI3K/Akt signaling pathway, inhibiting the formation of fat (Tang et al., 2017b). In addition, studies have confirmed that the synthesis of milk fat in mammary tissue is regulated by miRNAs. In goat mammary cells, transfection with miR-145 mimic increases the transcription of genes involved in milk fat synthesis, increasing lipid droplet sizes and increasing triglyceride synthesis (Wang et al., 2017a). Furthermore, miR-486 has been discovered to be highly expressed at the peak of lactation in dairy cows and to promote triglyceride synthesis by directly downregulating the PTEN gene in bovine mammary epithelial cells and activating the mTOR signaling pathway (Li et al., 2015a). The studies noted above indicate that miRNAs are involved in the regulation of fat synthesis. As a molecule with multiple functions, miR-27a-3p has been found to regulate the biological processes of cancer cells in a variety of cancers, such as esophageal (Wu et al., 2015), osteosarcoma (Liu et al., 2018a), and colon cancer (Su et al., 2019). In addition, studies have confirmed that miR-27a-3p participates in the regulation of milk fat synthesis (Tang et al., 2017a).
According to the information provided by TargetScan, miR-27a-3p targets more than 1,000 genes, and we performed Gene Ontology and Kyoto Encyclopedia of Genes and Genomes analysis of these target genes (Supplemental Table S3, https://doi.org/10.3168/jds .2020-18270). In addition to PPAR $\gamma$, these genes also include members of the milk fat regulatory network such as FASN, GPAM, and UGCG (Bionaz and Loor, 2008b), but whether miR-27a-3p can regulate these genes in bovine mammary epithelial cells to regulate milk fat synthesis has not been verified.

In our study, according to information provided by TargetScan, bta-miR-27a-3p targets the 84-91 position of the PPARG $3^{\prime} \mathrm{UTR}$; bta-miR-128 targets the 84-90 position of the PPARG $3^{\prime} \mathrm{UTR}$; and bta-miR-454 targets the 43-50 position of the PPARG $3^{\prime} \mathrm{UTR}$ (Supplemental Table S2, https://doi.org/10.3168/jds.2020 -18270). Studies in other species have confirmed that miR-27a-3p can regulate the expression of PPARG (Lv et al., 2017; Li et al., 2019b). Based on these studies, we hypothesized that miR-27a-3p is capable of regulating PPARG expression in MAC-T cells. Simultaneously, based on the TargetScan score (Supplemental Table S2) and the degree of change in the expression of each miRNA after LPS stimulation, we finally selected miR-27a-3p for subsequent research. In this study, we used dual luciferase reporter, qRT-PCR, and westernblot experiments to verify the targeted regulation of miR-27a-3p on PPARG. In the dual luciferase reporter experiment, cotransfection of the miR-27a-3p mimic and the PPARG-3'UTR wild-type plasmid significantly $(P<0.01)$ reduced the relative fluorescence intensity of $293 \mathrm{~T}$ cells; after the target site was mutated, the fluorescence intensity increased significantly $(P<0.01)$. After transfection of the mimic of miR-27a-3p, qRTPCR results showed that the expression of PPARG in MAC-T cells was significantly $(P<0.01)$ inhibited, whereas the transfection of its inhibitor obtained the opposite effect. Moreover, our Western blot results are consistent with those of qRT-PCR. The above results indicate that miR-27a-3p can regulate the expression of PPARG in MAC-T cells. Further oil red $\mathrm{O}$ staining and TAG assay results showed that miR-27a-3p expression was inversely related to MAC-T cell lipid droplet secretion and triglyceride synthesis. Therefore, miR-27a-3p is a potential regulator of milk fat synthesis in MAC-T cells. In addition, we stimulated MAC-T cells with LPS and transfected them with inhibitors of miR-27a-3p. Then, qRT-PCR was used to detect the expression of PPARG, and oil red $\mathrm{O}$ staining and TAG assays were used to detect the changes in milk fat synthesis. Our qRT-PCR results showed that although LPS stimulated MAC-T cells, its transfection with miR-27a-3p inhibitor partially reversed the inhibition of $P P A R G$ expression 


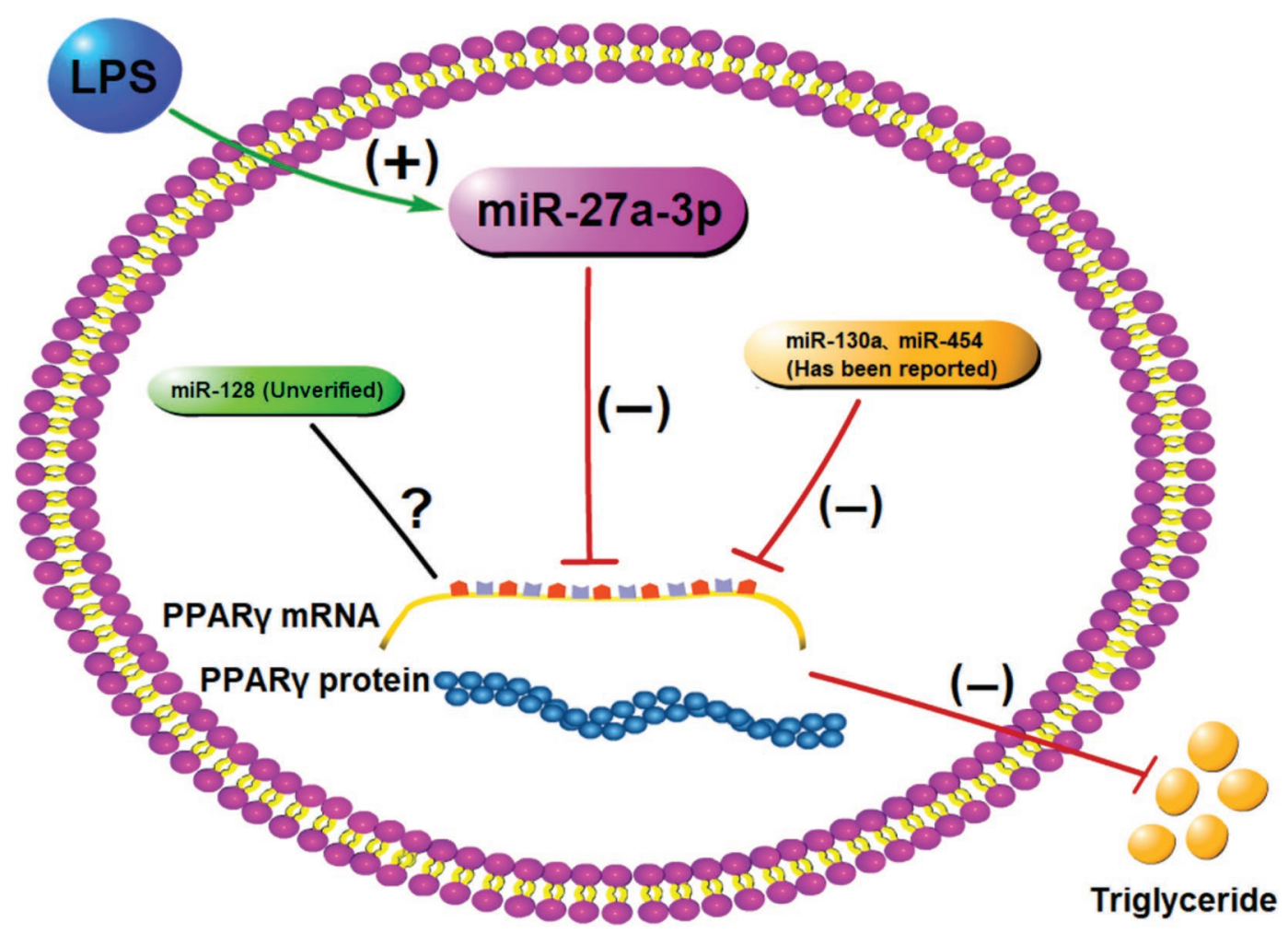

Figure 6. Lipopolysaccharide stimulation of dairy cow mammary epithelial (MAC-T) cells led to an increase in intracellular miR-27a-3p expression, and an increase in miR-27a-3p led to the inhibition of PPARG, which ultimately inhibited the synthesis of milk fat in MAC-T cells.

by LPS. Similarly, the miR-27a-3p inhibitor partially reversed the inhibitory effects of LPS on triglyceride synthesis and lipid droplet secretion in MAC-T cells. These results indicated that LPS can inhibit MAC-T cell milk fat synthesis through the LPS-miR-27a-3pPPARG pathway. Milk fat synthesis involves a complex and large network (Osorio et al., 2016). Regarding the PPARG gene, it has been reported that multiple miRNA, such as miR-130a and miR-454, participate in the process of lipid metabolism in bovine mammary epithelial cells through targeted regulation of $P P A R G$ expression (Yang et al., 2017; Zhang et al., 2019). Previous research reports using a mouse model showed that knockout of miR-128 inhibited the progression of Alzheimer's disease by targeting PPARG (Liu et al., 2019). However, whether miR-128 can regulate the expression of PPARG in MAC-T cells has not been verified. Among the genes targeted by miR-27a-3p, determination of whether more genes are involved in the process of milk fat synthesis in dairy cows still requires further exploration. Regarding the additional molecules involved in the milk fat synthesis of MAC-T cells, further research in the future is needed. In summary, our results demonstrate that LPS can upregulate miR-27a$3 \mathrm{p}$, which targets the PPARG gene, thereby inhibiting milk fat synthesis in MAC-T cells.

\section{CONCLUSIONS}

In conclusion, LPS can upregulate miR-27a-3p, which targets the PPARG gene, thereby inhibiting triglyceride synthesis in MAC-T cells. MiR-27a-3p is a potential regulatory factor of milk quality. Inhibition of miR-27a-3p restored the inhibition of milk fat synthesis and decreased PPARG expression induced by LPS to a certain extent in MAC-T cells (Figure 6). Our results reveal a potential molecular mechanism by which LPS inhibits milk fat synthesis in dairy cow mammary epithelial cells.

\section{ACKNOWLEDGMENTS}

All authors have contributed significantly. Ming-Qi Wang, Chang-Hai Zhou, and Shuai Cong performed the experiments. Ming-Qi Wang, Dong-Xu Han, Chang-Jiang Wang, and $\mathrm{Yu}$ Tian analyzed the data and contributed reagents. Ming-Qi Wang, Chang-Hai Zhou, and Jia-Bao Zhang wrote the manuscript. Hao Jiang and Bao Yuan supervised the study. All authors are in agreement with the content of the manuscript for publication. This study was supported by Chinese Agricultural Research Systems (Ministry of Agriculture of the PRC; CARS-37) and the Science and Technol- 
ogy Project of Jilin Province (SXGJSF2017-6). The authors declare no conflict of interest.

\section{REFERENCES}

Agarwal, V., G. W. Bell, J. W. Nam, and D. P. Bartel. 2015. Predicting effective microRNA target sites in mammalian mRNAs. Elife 4:e05005.

Bionaz, M., and J. J. Loor. 2008a. ACSL 1 , AGPAT6, FABP3, LPIN 1 , and SLC27A6 are the most abundant isoforms in bovine mammary tissue and their expression is affected by stage of lactation. J. Nutr. 138:1019-1024. https://doi.org/10.1093/jn/138.6.1019.

Bionaz, M., and J. J. Loor. 2008b. Gene networks driving bovine milk fat synthesis during the lactation cycle. BMC Genomics 9:366. https://doi.org/10.1186/1471-2164-9-366.

Brade, L., S. Hensen, and H. Brade. 2013. Evaluation of a LPS-based glycoconjugate vaccine against bovine Escherichia coli mastitis: Formation of LPS Abs in cows after immunization with E. coli core oligosaccharides conjugated to hemocyanine. Innate Immun. 19:368-377. https://doi.org/10.1177/1753425912462615.

Bushati, N., and S. M. Cohen. 2007. microRNA functions. Annu. Rev. Cell Dev. Biol. 23:175-205. https://doi.org/10.1146/annurev cellbio.23.090506.123406.

Chen, J., Y. Wu, Y. Sun, X. Dong, Z. Wang, Z. Zhang, Y. Xiao, and G. Dong. 2019. Bacterial lipopolysaccharide induced alterations of genome-wide DNA methylation and promoter methylation of lactation-related genes in bovine mammary epithelial cells. Toxins (Basel) 11:298. https://doi.org/10.3390/toxins11050298.

Creugny, A., A. Fender, and S. Pfeffer. 2018. Regulation of primary microRNA processing. FEBS Lett. 592:1980-1996. https://doi .org/10.1002/1873-3468.13067.

Griffiths-Jones, S., R. J. Grocock, S. van Dongen, A. Bateman, and A. J. Enright. 2006. miRBase: microRNA sequences, targets and gene nomenclature. Nucleic Acids Res. 34:D140-D144. https://doi.org/ $10.1093 / \mathrm{nar} / \mathrm{gkj} 112$.

Horak, M., J. Novak, and J. Bienertova-Vasku. 2016. Muscle-specific microRNAs in skeletal muscle development. Dev. Biol. 410:1-13. https://doi.org/10.1016/j.ydbio.2015.12.013.

$\mathrm{Hu}, \mathrm{X}$., N. Zhang, and Y. Fu. 2019. Role of liver X receptor in mastitis therapy and regulation of milk fat synthesis. J. Mammary Gland Biol. Neoplasia 24:73-83. https://doi.org/10.1007/s10911 $-018-9403-5$.

Invernizzi, G., B. J. Thering, M. A. McGuire, G. Savoini, and J. J. Loor. 2010. Sustained upregulation of stearoyl-CoA desaturase in bovine mammary tissue with contrasting changes in milk fat synthesis and lipogenic gene networks caused by lipid supplements. Funct. Integr. Genomics 10:561-575. https://doi.org/10.1007/ s10142-010-0179-y.

Jeong, C. H., W. N. Cheng, H. Bae, K. W. Lee, S. M. Han, M. C. Petriello, H. G. Lee, H. G. Seo, and S. G. Han. 2017. Bee venom decreases LPS-induced inflammatory responses in bovine mammary epithelial cells. J. Microbiol. Biotechnol. 27:1827-1836. https:// doi.org/10.4014/jmb.1706.06003.

Johnson, T. L., B. A. Fujimoto, R. Jimenez-Flores, and D. G. Peterson. 2010. Growth hormone alters lipid composition and increases the abundance of casein and lactalbumin mRNA in the MACT cell line. J. Dairy Res. 77:199-204. https://doi.org/10.1017/ S0022029910000087.

Khan, I. T., M. Nadeem, M. Imran, M. Asif, M. K. Khan, A. Din, and R. Ullah. 2019. Triglyceride, fatty acid profile and antioxidant characteristics of low melting point fractions of buffalo milk fat. Lipids Health Dis. 18:59. https://doi.org/10.1186/s12944-019-0995 -6 .

Lewis, B. P., C. B. Burge, and D. P. Bartel. 2005. Conserved seed pairing, often flanked by adenosines, indicates that thousands of human genes are microRNA targets. Cell 120:15-20. https://doi .org/10.1016/j.cell.2004.12.035.

Li, C., X. Wang, M. Kuang, L. Li, Y. Wang, F. Yang, and G. Wang. 2019a. UFL1 modulates NLRP3 inflammasome activation and protects against pyroptosis in LPS-stimulated bovine mammary epithelial cells. Mol. Immunol. 112:1-9. https://doi.org/10.1016/ j.molimm.2019.04.023.

Li, D., X. Xie, J. Wang, Y. Bian, Q. Li, X. Gao, and C. Wang. 2015a. MiR-486 regulates lactation and targets the PTEN gene in cow mammary glands. PLoS One 10:e0118284. https://doi.org/10 .1371/journal.pone.0118284.

Li, D. G., J. L. Li, D. Q. Sun, X. B. Sun, X. G. Sun, and Q. Liu. 2015b. Lentinan depresses 3T3-L1 fat cell formation by inhibiting PPAR $\gamma /$ AKT signaling pathway. Genet. Mol. Res. 14:8084-8090. https://doi.org/10.4238/2015.July.17.17.

Li, X., P. Jiang, H. Yu, Y. Yang, L. Xia, R. Yang, X. Fang, and Z. Zhao. 2019b. miR-21-3p targets Elovl5 and regulates triglyceride production in mammary epithelial cells of cow. DNA Cell Biol. 38:352-357. https://doi.org/10.1089/dna.2018.4409.

Li, Y., H. Zhu, X. Wei, H. Li, Z. Yu, H. Zhang, and W. Liu. 2017. LPS induces HUVEC angiogenesis in vitro through miR-146a-mediated TGF-31 inhibition. Am. J. Transl. Res. 9:591-600.

Liu, J., G. Li, C. Chen, D. Chen, and Q. Zhou. 2017. MiR-6835 promoted LPS-induced inflammation of HUVECs associated with the interaction between TLR-4 and AdipoR1 in lipid rafts. PLoS One 12:e0188604. https://doi.org/10.1371/journal.pone.0188604.

Liu, J., M. Li, X. Liu, F. Liu, and J. Zhu. 2018a. miR-27a-3p promotes the malignant phenotypes of osteosarcoma by targeting ten-eleven translocation 1. Int. J. Oncol. 52:1295-1304. https://doi.org/10 $.3892 /$ ijo.2018.4275.

Liu, L., Y. Lin, L. Liu, Y. Bian, L. Zhang, X. Gao, and Q. Li. 2015. 14$3-3 \gamma$ regulates lipopolysaccharide-induced inflammatory responses and lactation in dairy cow mammary epithelial cells by inhibiting $\mathrm{NF}-\kappa \mathrm{B}$ and MAPKs and up-regulating mTOR signaling. Int. J. Mol. Sci. 16:16622-16641. https://doi.org/10.3390/ijms160716622.

Liu, L., Y. Lin, L. Liu, L. Wang, Y. Bian, X. Gao, and Q. Li. 2016a. Regulation of peroxisome proliferator-activated receptor gamma on milk fat synthesis in dairy cow mammary epithelial cells. In Vitro Cell. Dev. Biol. Anim. 52:1044-1059. https://doi.org/10.1007/ s11626-016-0059-4.

Liu, L., L. I. Zhang, Y. E. Lin, Y. Bian, X. Gao, B. O. Qu, and Q.

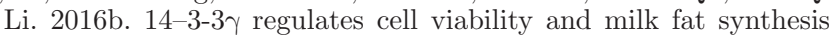
in lipopolysaccharide-induced dairy cow mammary epithelial cells. Exp. Ther. Med. 11:1279-1287. https://doi.org/10.3892/etm.2016 .3029 .

Liu, X., Y. Yang, P. Jiang, X. Li, Y. Ge, Y. Cao, Z. Zhao, X. Fang, and X. Yu. 2018b. Effect of QSOX1 on cattle carcass traits as well as apoptosis and triglyceride production in bovine fetal fibroblasts and mammary epithelial cells. J. Vet. Med. Sci. 80:1329-1336. https://doi.org/10.1292/jvms.17-0705.

Liu, Y., Y. Zhang, P. Liu, H. Bai, X. Li, J. Xiao, Q. Yuan, S. Geng, H. Yin, H. Zhang, Z. Wang, J. Li, S. Wang, and Y. Wang. 2019. MicroRNA-128 knockout inhibits the development of Alzheimer's disease by targeting PPAR $\gamma$ in mouse models. Eur. J. Pharmacol. 843:134-144. https://doi.org/10.1016/j.ejphar.2018.11.004.

Lu, J., X. Wang, W. Zhang, L. Liu, X. Pang, S. Zhang, and J. Lv. 2016. Comparative proteomics of milk fat globule membrane in different species reveals variations in lactation and nutrition. Food Chem. 196:665-672. https://doi.org/10.1016/j.foodchem.2015.10 .005 .

Lu, T. X., and M. E. Rothenberg. 2018. MicroRNA. J. Allergy Clin. Immunol. 141:1202-1207. https://doi.org/10.1016/j.jaci.2017.08 .034 .

Lv, X., J. Yan, J. Jiang, X. Zhou, Y. Lu, and H. Jiang. 2017. MicroRNA-27a-3p suppression of peroxisome proliferator-activated receptor- $\gamma$ contributes to cognitive impairments resulting from sevoflurane treatment. J. Neurochem. 143:306-319. https://doi .org/10.1111/jnc. 14208 .

Ma, F., Z. Li, J. Cao, X. Kong, and G. Gong. 2019. A TGFBR2/ SMAD2/DNMT1/miR-145 negative regulatory loop is responsible for LPS-induced sepsis. Biomed. Pharmacother. 112:108626. https: //doi.org/10.1016/j.biopha.2019.108626.

Marion-Letellier, R., G. Savoye, and S. Ghosh. 2016. Fatty acids, eicosanoids and PPAR gamma. Eur. J. Pharmacol. 785:44-49. https:/ /doi.org/10.1016/j.ejphar.2015.11.004. 
Martin, E. C., A. T. Qureshi, V. Dasa, M. A. Freitas, J. M. Gimble, and T. A. Davis. 2016. MicroRNA regulation of stem cell differentiation and diseases of the bone and adipose tissue: Perspectives on miRNA biogenesis and cellular transcriptome. Biochimie 124:98-111. https://doi.org/10.1016/j.biochi.2015.02.012.

Mohr, A. M., and J. L. Mott. 2015. Overview of microRNA biology. Semin. Liver Dis. 35:3-11. https://doi.org/10.1055/s-0034-1397344.

Ning, C., G. Li, L. You, Y. Ma, L. Jin, J. Ma, X. Li, M. Li, and H. Liu. 2017. MiR-185 inhibits 3T3-L1 cell differentiation by targeting SREBP-1. Biosci. Biotechnol. Biochem. 81:1747-1754. https:/ /doi.org/10.1080/09168451.2017.1347485.

Ning, L. T., G. Z. Dong, C. Ao, D. G. Zhang, K. Erdene, F. Q. Zhang, J. Wen, and T. L. Zhang. 2018. Effects of continuous low dose infusion of lipopolysaccharide on inflammatory responses, milk production and milk quality in dairy cows. J. Anim. Physiol. Anim. Nutr. (Berl.) 102:e262-e269. https://doi.org/10.1111/jpn.12737.

Osorio, J. S., J. Lohakare, and M. Bionaz. 2016. Biosynthesis of milk fat, protein, and lactose: Roles of transcriptional and posttranscriptional regulation. Physiol. Genomics 48:231-256. https://doi .org/10.1152/physiolgenomics.00016.2015.

Perruchot, M. H., M. Arevalo-Turrubiarte, F. Dufreneix, L. Finot, V. Lollivier, E. Chanat, F. Mayeur, and F. Dessauge. 2016. Mammary Epithelial Cell Hierarchy in the Dairy Cow Throughout Lactation. Stem Cells Dev. 25:1407-1418. https://doi.org/10.1089/scd.2016 .0098 .

Qi, C., J. Sun, Y. Xia, R. Yu, W. Wei, J. Xiang, Q. Jin, H. Xiao, and X. Wang. 2018. Fatty acid profile and the sn-2 position distribution in triacylglycerols of breast milk during different lactation stages. J. Agric. Food Chem. 66:3118-3126. https://doi.org/10 $.1021 /$ acs.jafc.8b01085.

Ramer, R., K. Heinemann, J. Merkord, H. Rohde, A. Salamon, M. Linnebacher, and B. Hinz. 2013. COX-2 and PPAR- $\gamma$ confer cannabidiol-induced apoptosis of human lung cancer cells. Mol. Cancer Ther. 12:69-82. https://doi.org/10.1158/1535-7163.MCT-12-0335.

Schennink, A., H. Bovenhuis, K. M. Leon-Kloosterziel, J. A. Van Arendonk, and M. H. Visker. 2009. Effect of polymorphisms in the FASN, OLR1, PPARGC1A, PRL and STAT5A genes on bovine milk-fat composition. Anim. Genet. 40:909-916. https://doi.org/ 10.1111/j.1365-2052.2009.01940.x.

Schmitz, S., M. W. Pfaffl, H. H. Meyer, and R. M. Bruckmaier. 2004. Short-term changes of mRNA expression of various inflammatory factors and milk proteins in mammary tissue during LPS-induced mastitis. Domest. Anim. Endocrinol. 26:111-126. https://doi.org/ 10.1016/j.domaniend.2003.09.003.

Shao, X., M. Wang, X. Wei, S. Deng, N. Fu, Q. Peng, Y. Jiang, L. Ye, J. Xie, and Y. Lin. 2016. Peroxisome proliferator-activated receptor- $\gamma$ : master regulator of adipogenesis and obesity. Curr. Stem Cell Res. Ther. 11:282-289. https://doi.org/10.2174/ 1574888X10666150528144905.

Shen, B., Q. Pan, Y. Yang, Y. Gao, X. Liu, W. Li, Y. Han, X. Yuan, Y. Qu, and Z. Zhao. 2017. miR-224 affects mammary epithelial cell apoptosis and triglyceride production by downregulating ACADM and ALDH2 genes. DNA Cell Biol. 36:26-33. https://doi.org/10 .1089 /dna.2016.3540.

Shen, B., L. Zhang, C. Lian, C. Lu, Y. Zhang, Q. Pan, R. Yang, and Z. Zhao. 2016. Deep sequencing and screening of differentially expressed MicroRNAs related to milk fat metabolism in bovine primary mammary epithelial cells. Int. J. Mol. Sci. 17:200. https:/ /doi.org/10.3390/ijms17020200.

Shi, H., W. Zhao, C. Zhang, K. Shahzad, J. Luo, and J. J. Loor. 2016. Transcriptome-wide analysis reveals the role of PPAR $\gamma$ controlling the lipid metabolism in goat mammary epithelial cells. PPAR Res. 2016:9195680. https://doi.org/10.1155/2016/9195680.

Shi, H. B., J. Luo, D. W. Yao, J. J. Zhu, H. F. Xu, H. P. Shi, and J. J. Loor. 2013. Peroxisome proliferator-activated receptor- $\gamma$ stimulates the synthesis of monounsaturated fatty acids in dairy goat mammary epithelial cells via the control of stearoyl-coenzyme A desaturase. J. Dairy Sci. 96:7844-7853. https://doi.org/10.3168/ jds.2013-7105.

Song, Y. S., H. W. Joo, I. H. Park, G. Y. Shen, Y. Lee, J. H. Shin, H. Kim, and K. S. Kim. 2017. Bone marrow mesenchymal stem cell-derived vascular endothelial growth factor attenuates cardiac apoptosis via regulation of cardiac miRNA-23a and miRNA-92a in a rat model of myocardial infarction. PLoS One 12:e179972. https://doi.org/10.1371/journal.pone.0179972.

Su, C., D. P. Huang, J. W. Liu, W. Y. Liu, and Y. O. Cao. 2019. miR$27 \mathrm{a}-3 \mathrm{p}$ regulates proliferation and apoptosis of colon cancer cells by potentially targeting BTG1. Oncol. Lett. 18:2825-2834. https:/ /doi.org/10.3892/ol.2019.10629.

Tang, K. Q., Y. N. Wang, L. S. Zan, and W. C. Yang. 2017a. miR27a controls triacylglycerol synthesis in bovine mammary epithelial cells by targeting peroxisome proliferator-activated receptor gamma. J. Dairy Sci. 100:4102-4112. https://doi.org/10.3168/jds .2016-12264.

Tang, R., F. Ma, W. Li, S. Ouyang, Z. Liu, and J. Wu. 2017b. miR206-3p inhibits 3T3-L1 cell adipogenesis via the c-Met/PI3K/ Akt pathway. Int. J. Mol. Sci. 18:1510. https://doi.org/10.3390/ ijms 18071510

Wang, F., S. E. Mullican, J. R. Dispirito, L. C. Peed, and M. A. Lazar. 2013. Lipoatrophy and severe metabolic disturbance in mice with fat-specific deletion of PPAR $\gamma$. Proc. Natl. Acad. Sci. USA 110:18656-18661. https://doi.org/10.1073/pnas.1314863110.

Wang, H., H. Shi, J. Luo, Y. Yi, D. Yao, X. Zhang, G. Ma, and J. J. Loor. 2017a. MiR-145 regulates lipogenesis in goat mammary cells via targeting INSIG1 and epigenetic regulation of lipid-related genes. J. Cell. Physiol. 232:1030-1040. https://doi.org/10.1002/ jcp. 25499 .

Wang, J., X. Zhang, X. He, B. Yang, H. Wang, X. Shan, C. Li, D. Sun, and $\mathrm{R}$. Wu. 2018a. LPS-induced reduction of triglyceride synthesis and secretion in dairy cow mammary epithelial cells via decreased SREBP1 expression and activity. J. Dairy Res. 85:439-444. https: //doi.org/10.1017/S0022029918000547.

Wang, M., M. Liu, J. Sun, L. Jia, S. Ma, J. Gao, Y. Xu, H. Zhang, S. Y. Tsang, and X. Li. 2017b. MicroRNA-27a-3p affects estradiol and androgen imbalance by targeting Creb1 in the granulosa cells in mouse polycytic ovary syndrome model. Reprod. Biol. 17:295304. https://doi.org/10.1016/j.repbio.2017.09.005.

Wang, Q., M. U. Imam, Z. Yida, and F. Wang. 2017c. Peroxisome proliferator-activated receptor gamma (PPAR $\gamma$ ) as a target for concurrent management of diabetes and obesity-related cancer. Curr. Pharm. Des. 23:3677-3688. https://doi.org/10.2174/ 1381612823666170704125104

Wang, T., H. Lee, and Y. Zhen. 2018b. Responses of MAC-T cells to inhibited stearoyl-CoA desaturase 1 during cis-9, trans-11 conjugated linoleic acid synthesis. Lipids 53:647-652. https://doi.org/ 10.1002/lipd.12077.

Wang, Y., W. Guo, H. Xu, K. Tang, L. Zan, and W. Yang. 2019. Melatonin suppresses milk fat synthesis by inhibiting the mTOR signaling pathway via the MT1 receptor in bovine mammary epithelial cells. J. Pineal Res. 67:e12593. https://doi.org/10.1111/jpi.12593.

Wu, T., C. Wang, L. Ding, Y. Shen, H. Cui, M. Wang, and H. Wang. 2016. Arginine relieves the inflammatory response and enhances the casein expression in bovine mammary epithelial cells induced by lipopolysaccharide. Mediators Inflamm. 2016:9618795. https:// doi.org/10.1155/2016/9618795.

Wu, X. Z., K. P. Wang, H. J. Song, J. H. Xia, Y. Jiang, and Y. L. Wang. 2015. MiR-27a-3p promotes esophageal cancer cell proliferation via F-box and WD repeat domain-containing 7 (FBXW7) suppression. Int. J. Clin. Exp. Med. 8:15556-15562.

Xi, T., F. Jin, Y. Zhu, J. Wang, L. Tang, Y. Wang, D. S. Liebeskind, F. Scalzo, and Z. He. 2018. miR-27a-3p protects against blood-brain barrier disruption and brain injury after intracerebral hemorrhage by targeting endothelial aquaporin-11. J. Biol. Chem. 293:20041-20050. https://doi.org/10.1074/jbc.RA118.001858.

Xia, X., Y. Che, Y. Gao, S. Zhao, C. Ao, H. Yang, J. Liu, G. Liu, W. Han, Y. Wang, and L. Lei. 2016. Arginine supplementation recovered the IFN- $\gamma$-mediated decrease in milk protein and fat synthesis by inhibiting the GCN2/eIF2alpha pathway, which induces autophagy in primary bovine mammary epithelial cells. Mol. Cells 39:410-417. https://doi.org/10.14348/molcells.2016.2358.

Xu, L., X. Ma, N. K. Verma, D. Wang, O. Gavrilova, R. L. Proia, T. Finkel, and E. Mueller. 2018. Ablation of PPAR $\gamma$ in subcutaneous 
fat exacerbates age-associated obesity and metabolic decline. Aging Cell 17:e12721.

Yang, W., C. Yang, J. Luo, Y. Wei, W. Wang, and Y. Zhong. 2018. Adiponectin promotes preadipocyte differentiation via the PPAR pathway. Mol. Med. Rep. 17:428-435.

Yang, W. C., W. L. Guo, L. S. Zan, Y. N. Wang, and K. Q. Tang. 2017. Bta-miR-130a regulates the biosynthesis of bovine milk fat by targeting peroxisome proliferator-activated receptor gamma. J Anim. Sci. 95:2898-2906. https://doi.org/10.2527/jas2017.1504.

Yu, G. M., H. Kubota, M. Okita, and T. Maeda. 2017. The antiinflammatory and antioxidant effects of melatonin on LPS-stimulated bovine mammary epithelial cells. PLoS One 12:e178525. https://doi.org/10.1371/journal.pone.0178525.

Zebisch, K., V. Voigt, M. Wabitsch, and M. Brandsch. 2012. Protocol for effective differentiation of 3T3-L1 cells to adipocytes. Anal. Biochem. 425:88-90. https://doi.org/10.1016/j.ab.2012.03.005.

Zhang, L., X. Hou, L. Sun, T. He, R. Wei, M. Pang, and R. Wang. 2018a. Staphylococcus aureus bacteriophage suppresses LPS-induced inflammation in MAC-T bovine mammary epithelial cells. Front. Microbiol. 9:1614. https://doi.org/10.3389/fmicb.2018 .01614 .

Zhang, M. Q., J. L. Gao, X. D. Liao, T. H. Huang, M. N. Zhang, M. Q. Wang, Y. Tian, J. Bai, and C. H. Zhou. 2019. miR-454 regulates triglyceride synthesis in bovine mammary epithelial cells by targeting PPAR- $\gamma$. Gene 691:1-7. https://doi.org/10.1016/j.gene 2018.12.048

Zhang, P., L. Q. Li, D. Zhang, and Y. Shen. 2018b. Over-expressed miR-27a-3p inhibits inflammatory response to spinal cord injury by decreasing TLR4. Eur. Rev. Med. Pharmacol. Sci. 22:54165423.

Zhang, T., B. Shao, and G. A. Liu. 2017. Rosuvastatin promotes the differentiation of peripheral blood monocytes into M2 macrophages in patients with atherosclerosis by activating PPAR- $\gamma$. Eur. Rev. Med. Pharmacol. Sci. 21:4464-4471.

Zheng, Y., C. Zhu, L. Ma, P. Shao, C. Qin, P. Li, Q. Cao, X. Ju, G. Cheng, Q. Zhu, X. Gu, and L. Hua. 2017. miRNA-154-5p inhibits proliferation, migration and invasion by targeting E2F5 in prostate cancer cell lines. Urol. Int. 98:102-110. https://doi.org/ $10.1159 / 000445252$.

\section{ORCIDS}

Ming-Qi Wang @ https://orcid.org/0000-0002-0434-9619

Chang-Hai Zhou $\odot$ https://orcid.org/0000-0003-4750-2107

Shuai Cong ๑ https://orcid.org/0000-0002-4771-7880

Dong-Xu Han 잔 https://orcid.org/0000-0002-9920-0904

Chang-Jiang Wang (® https://orcid.org/0000-0002-9284-9305

Yu Tian $\odot$ https://orcid.org/0000-0002-5483-0611

Jia-Bao Zhang (® https://orcid.org/0000-0001-8533-4744

Hao Jiang @ https://orcid.org/0000-0003-2008-6166

Bao Yuan () https://orcid.org/0000-0003-3490-0755 